\title{
Potential Spore-Forming Probiotics Isolated from Ntoba mbodi, Alkaline Fermented Leaves of Cassava from the Republic of the Congo
}

\author{
Alain Brice Mbozo Vouidibio ${ }^{1}$, Christian Aimé Kayath ${ }^{1,2}$, Etienne Nguimbi $^{1}$, Augustin Aimé Lebonguy ${ }^{2}$ and \\ Simon Charles Kobawila ${ }^{1}$
}

${ }^{1}$ Laboratoire de Biologie Cellulaire et Moléculaire, Faculté des Sciences et Techniques, Université Marien NGOUABI, BP 69 Brazzaville, République du Congo

${ }^{2}$ Institut National de Recherche en Sciences Exactes et Naturelles (IRSEN), Avenue de l'Auberge Gascogne, BP 2400 Brazzaville, République du Congo

\begin{abstract}
This work aimed to characterize strains of Bacillus with fermenting properties for the production of $\alpha$-amylases, proteases and pectinases and to evaluate their probiotic abilities. The detection of the fermentative enzymes of the different strains was carried out on solid media containing a specific substrate. Stress resistance of gastrointestinal transit was evaluated in vitro and the diffusion method in agar medium and antibiotic susceptibility of targeted strains was used to assess antibacterial activity. As results, evaluation of the fermentative potential revealed good proteolytic (100\%), pectinolytic (68.42\%) and amylolytic (57.90 \%) activities. The evaluation of the probiotic potential also revealed promising results: resistance to gastric acid from two strains with a survival rate above $70 \%$ at pH 2.5; a growth in the presence of $0.3 \%$ biliary salt and an inhibitory capacity against Staphylococcus aureus, Serratia odorifera and Salmonella spp. Intrinsic resistance of the strains was observed with respect to cefoperazone and amoxicillin.
\end{abstract}

Keywords: Potential fermenting, Bacillus, Probiotics, Ntoba mbodi

\section{Introduction}

Ntoba mbodi is an alkaline-fermented food derived from the spontaneous fermentation of the leaves of cassava (Manihot esculenta Crantz). The biotransformation of cassava leaves is characterized mainly by the alkalization of the fermentation medium, the softening and browning of the leaves and the detoxification of the fermented product [21]. Bacteria of the genus Bacillus are the main microorganisms associated with such fermentation and can develop sporeforming bacteria to resist the stresses generated by nutritional deficiency and unfavorable physicochemical conditions. The production processes of ntoba mbodi are of the artisanal type making with non-sterile material leading to a great variability in the quality of the final product.

Moreover, since the discovery of antibiotics, by the time of drafting this paper anti-biotherapy and anti-bioprevention are the only way to face human and animal health [4]. Bacterial world has been developed mechanisms of multi resistance to antibiotics [16]. This situation led to search for new strategies to find new products for innovative alternatives. In the majority of cases, studies are focused on probiotics basing on living microorganisms administered in an adequate amount. Probiotics can confer a beneficial effect on the host. Since probiotics bacteria associated in food have been also used [11]. They are carried in the majority of cases by fermented products such as yogurts, fermented milks and cheeses [9]. However, most known probiotics do not survive the technological treatments applied in the product manufacture of the various foods and the storage conditions. In addition, some probiotic bacteria do not reach the intestine due to stress problems generated during the transit inside gastro-digestive tract and competition with pathogenic and indigenous germs $[6,12]$.
Several studies have been proposed to study spore-forming bacteria by using them as probiotics in order to better resist the environmental stresses and the gastrointestinal transit [26]. Ntoba mbodi constitutes a potential source for the isolation of probiotics spore-forming bacteria.

The aim of this work is to select strains of Bacillus with interesting fermentation and probiotic properties, with a view to the production of ferment for controlled fermentation during the production of ntoba mbodi.

\section{Material and Methods}

\subsection{Strains}

Nineteen (19) spore-forming bacteria belonging to eight (8) species of Bacillus were selected for this study. Strains were isolated from ntoba mbodi and then identified by phenotyping and sequencing of the $16 \mathrm{~S}$ rDNA, gyr A, gyr B and rpo B genes, as reported by [37], (submitted paper). Strains and the corresponding codes were assigned in Table I.

Table I: Identification of the strains studied

\begin{tabular}{|c|c|c|c|}
\hline Code & Identification & Code & Identification \\
\hline NM 21 & B. pumilus & NM 52 & B. altitudinis \\
\hline NM 29 & B. pumilus & NM 56 & B. megaterium \\
\hline NM 33 & B. pumilus & NM 65 & B. megaterium \\
\hline NM 34 & B. pumilus & NM 35 & B. subtilis \\
\hline NM 67 & B. pumilus & NM 39 & B. subtilis \\
\hline NM 1 & B. safensis & NM 76 & B. amyloliquefaciens \\
\hline NM 3 & B. safensis & NM 78 & B. amyloliquefaciens \\
\hline NM 5 & B. safensis & NM 74 & B. licheniformis \\
\hline NM 16 & B. altitudinis & NM 73 & Lysinibacillus $\mathrm{sp}$ \\
\hline NM 24 & B. altitudinis & & \\
\hline
\end{tabular}




\section{International Journal of Science and Research (IJSR) \\ ISSN (Online): 2319-7064}

Index Copernicus Value (2015): 78.96 | Impact Factor (2015): 6.391

\subsection{Evaluation of fermentative potential spore-forming bacteria}

The ability to produce three enzymes ( $\alpha$-amylase, protease and pectinase) involved in the biotransformation of cassava leaves has been investigated in different bacteria.

\section{Proteolytic activity}

The proteolytic activity of the bacteria has been determined by depositing Wattman paper disks on nutrient agar supplemented with $5 \%$ skim milk. $10 \mu \mathrm{L}$ was added to each sterile disk and then associated with an overnight culture performed with appropriated strains. After incubation at 37 ${ }^{\circ} \mathrm{C}$ for $24 \mathrm{~h}$ under aerobic conditions, the proteolysis is revealed by clear halos around the disks as described by [38].

\section{Pectinolytic activity}

To perform pectinolytic activity strains was carried out according to the procedure described by $[5,19]$. Briefly, strains have been seeded in a test tube containing nutrient agar, $0.6 \%$ calcium chloride and $1 \mathrm{~mL}$ of $1 \%$ pectin. Activity was assessed after $96 \mathrm{~h}$ of incubation at $37^{\circ} \mathrm{C}$ under aerobic conditions. Pectinolytic activity is viewing by the liquefaction of the agar.

\section{Amylolytic activity}

The amylolytic activity was demonstrated on nutrient agar with $1 \%$ of soluble starch. Sterile Wattman paper disks were deposited on the surface of agar medium. $10 \mu \mathrm{L}$ of an overnight culture was added to each sterile disk and deposit on nutrient agar supplemented with starch. After incubation at $37^{\circ} \mathrm{C}$ for $24 \mathrm{~h}$ under aerobic conditions, the hydrolysis of the starch is revealed by a translucent zone around the disks [14].

\subsection{Evaluation of potential spore-forming probiotics}

Four (4) screening criteria for probiotics were evaluated. These include resistance to acid $\mathrm{pH}$, tolerance to biliary salt, antibacterial activity and antibiotic resistances.

\section{Evaluation of acid $\mathrm{pH}$ resistance}

This test was carried out according to the method described by [17] in a medium simulating gastric barrier. Pure cultures of strains to be tested were cultured aerobically for $6 \mathrm{~h}$ in three test tubes containing $10 \mathrm{~mL}$ of the nutrient broth $(\mathrm{pH}$ 7.2). The bacterial cells were then recovered after centrifugation (13000 rpm / $4 \mathrm{~min}$ ). The pellet was washed twice with sterile saline buffer phosphate (PBS), and then suspended again in three test tubes containing $10 \mathrm{~mL}$ of the nutrient broth adjusted respectively to $\mathrm{pH} 2.0, \mathrm{pH} 2.5$ and $\mathrm{pH} 4.0$ with $1 \mathrm{~N} \mathrm{HCl}$ solution. At $\mathrm{t}_{0}$ and after $4 \mathrm{~h}$ of incubation at $37{ }^{\circ} \mathrm{C}$ under aerobic conditions. $1 \mathrm{~mL}$ of the different bacterial suspensions was taken and serial serially diluted in peptone water for enumeration on nutrient agar.

The survival percent of the different strains was calculated by the following equation:

Survival rate $(\%)=\left[\log \mathrm{UFC}\right.$ at $\mathrm{t}_{4 \mathrm{~h}} / \log \mathrm{UFC}$ at $\left.\mathrm{t}_{0 \mathrm{~h}}\right] \times 100$

Three independent experiments were performed and each test was performed three times.

\section{Assessment of Biliary salt tolerance}

Strain growth in the presence of biliary salt was evaluated according to the method described by [36]. Briefly each strain $(0.2 \mathrm{~mL}$ of concentrated culture) was inoculated into three test tubes containing $10 \mathrm{~mL}$ of the nutrient broth containing $0.3 \%, 1 \%$ and $2 \%(\mathrm{w} / \mathrm{v})$ bovine bile (Oxgall, Sigma). $\mathrm{A} \mathrm{t}_{0}$ and after $4 \mathrm{~h}$ of incubation at $37{ }^{\circ} \mathrm{C}$ under aerobic conditions, $1 \mathrm{~mL}$ of the various suspensions was taken and diluted with peptone water for counting on nutrient agar.

The survival percentage of the different strains was calculated by the following equation:

Survival rate $(\%)=\left[\log U F C\right.$ at $\mathrm{t}_{4 \mathrm{~h}} / \log \mathrm{UFC}$ at $\left.\mathrm{t}_{0 \mathrm{~h}}\right] \times 100$

Three independent experiments were performed and each test was performed three times.

\section{Antibiotics sensitivity}

The diffusion method in agar medium was applied as standardized by the Laboratory and Clinical Standards Institution [7]. Each strain was inoculated onto trypticase soya agar. After an overnight incubation at $37{ }^{\circ} \mathrm{C}, 4$ to 5 well-isolated pure colonies were transferred into $5 \mathrm{~mL}$ of trypticase soy broth. After baking at $37{ }^{\circ} \mathrm{C}$ for $3 \mathrm{~h}$, this bacterial suspension was then adjusted to turbidity close to 0.5 of McFarland range, which corresponds to an inoculum of about 1 to $2.10^{8} \mathrm{CFU} / \mathrm{ml}$. Inoculum was then uniformly spread on the surface of the Mueller-Hinton agar. Petri dishes were dried for $10 \mathrm{~min}$ at room temperature. Finally, the antibiotic discs were deposited on the agar. Four (4) antibiotic discs chloramphenicol $(30 \mu \mathrm{g})$; Erythromycin (15 $\mu \mathrm{g})$; Amoxicillin $(25 \mu \mathrm{g})$ and cefoperazone $(30 \mu \mathrm{g})$ were plating incubated at $35 \pm 1{ }^{\circ} \mathrm{C}$ under aerobic conditions for $18 \mathrm{~h}$, the diameter of each zone of growth inhibition around each disc was measured. The results were interpreted according to the recommendations of the "Committee of the French Society of Antibiogram (CASFA, 2015). The results are expressed as (S) sensitive, (I) intermediate and (R) resistant.

\section{In vitro antagonistic capability}

Four (4) pathogenic strains provided by the medical-surgical clinic COGEMO (Republic of Congo) were used. These include S. aureus, Serratia odorifera, Salmonella sp, and Escherichia coli. All strains were isolated from patients.

The solid-state diffusion method described by [33] has been used to demonstrate the inhibitory effect of selected strains. $100 \mu \mathrm{L}$ with D.O 0.8 of the pathogenic strain were uniformly spread on the surface of the Mueller-Hinton agar. After incubation for $30 \mathrm{~min}$ at $37^{\circ} \mathrm{C}$., sterile discs previously impregnated with $3 \mu \mathrm{L}$ of an overnight culture of strain supposed to inhibit were deposited on the surface of the agar. Plates were dried at room temperature for $15 \mathrm{~min}$. Petri dishes have been placed at $4{ }^{\circ} \mathrm{C}$ for $4 \mathrm{~h}$ to allow diffusion of the substances responsible for the interaction. Finally an overnight incubation was done at $37^{\circ} \mathrm{C}$.

The appearance of a zone of inhibition with a diameter greater than $2 \mathrm{~mm}$ reveals an inhibition of the growth of the pathogen by the strain tested [10]. 


\section{International Journal of Science and Research (IJSR) \\ ISSN (Online): 2319-7064}

Index Copernicus Value (2015): 78.96 | Impact Factor (2015): 6.391

\section{Results}

\subsection{Evaluation of fermentative potential spore-forming bacteria}

The results of the enzymatic activities of the different strains are illustrated in figure 1. Five strains were positive for the three enzymatic activities, NM 16, NM 52, NM 35, NM 39 and NM 74 strains. Two strains presented a significant activity with 3-fold (NM 39 and NM 78). In contrast, all strains exhibited at least two enzymatic activities. The latter was most pronounced at $42.11 \%$ of the strains (NM 39, NM 78, NM 74, NM 65, NM 52, NM 16, NM 67 and NM 33). About $68.42 \%$ of the bacteria revealed pectinolytic activity (NM 33, NM 1, NM 39 and NM 74). Only strains NM 33, NM 1, NM 39 and NM 74, corresponding respectively to Bacillus pumilus, $\quad B$. safensis, $B$. subtilis and $B$. licheniformis showed a strong pectinolytic activity. Finally $57.90 \%$ of the bacteria showed amylolytic activity. The latter was more important in the strains NM 39, NM 56, NM 78, NM 76 and NM 74 (B. subtilis, B. megaterium, B. amyloliquefaciens and $B$. licheniformis).

\subsection{Evaluation of probiotic potential}

The results of the behavior of the various strains subjected to the action of acid $\mathrm{pH}(2.0,2.5$ and 4.0) are shown in figure 2 and show that almost all the strains survived after 4 hours of acid stress. In general, the resistance to acid conditions decreases with the lowering of the $\mathrm{pH}$ of the medium until cancellation (absence of viability) for the NM 73 strain
(Lysinibacillus $\mathrm{sp}$ ) at $\mathrm{pH}$ 2.0. The strains of B. subtilis (NM 35 and NM 39) and B. amyloliquefaciens (NM 76 and NM 78) showed better resistance to low $\mathrm{pH}$, respectively with a survival rate of $81 \%, 83 \%, 73 \%$ and $72 \%$ at $\mathrm{pH} 2.0$ and $95 \%, 97 \%, 83 \%$ and $86 \%$ at $\mathrm{pH} 2.5$. All strains could be grown at $\mathrm{pH} 4.0$.

The study of resistance to biliary juice revealed that all the strains tested tolerate the bile "Oxgall". Indeed, the strains were affected by the presence of $3 \%$ bile juice, but most strains survived. Moreover, a tolerance to the exposure of the biliary juice of almost all strains was observed at concentrations $0.3 \%$ and $1 \%$ (Figure 3 ). The best tolerance profiles were shown by $B$. safensis (NM 5), B. subtilis (NM 39), B. amyloliquefaciens (NM 75) and B. megaterium (NM $56)$.

Table II presents the class of each strain deduced from the diameter of the zone of inhibition of their growth. The results obtained show a high resistance of the strains to the various antibiotics tested. Indeed, all strains were resistant to amoxicillin and cefoperazone, with the exception of strain NM 21, which is sensitive to cefoperazone. Ten (10) strains resisted the inhibitory effect of chloramphenicol. In contrast, all strains were susceptible to erythromycin. No strain was either sensitive or resistant to all four antibiotics. The breakdown of the percentage categories gives $57.50 \%$ resistance, $34.17 \%$ sensitive and $8.33 \%$ intermediate category.

Table II: Antibiotic sensitivities of different strains. R: resistant; S: sensitive; I: intermediate

\begin{tabular}{|c|c|c|c|c|c|c|c|c|c|c|c|c|c|c|c|c|c|c|c|}
\hline & \multicolumn{19}{|c|}{ Bacterial strains } \\
\hline & NM & NM & NM & NM & NM & NM & NM & NM & $\mathrm{NM}$ & NM & $\mathrm{NM}$ & NM & NM & NM & NM & NM & NM & NM & $\mathrm{NM}$ \\
\hline Antibiotics & 21 & 29 & 33 & 34 & 67 & 1 & 3 & 5 & 16 & 24 & 52 & 56 & 65 & 35 & 39 & 76 & 78 & 74 & 73 \\
\hline Chloramphenicol & $\mathrm{R}$ & $\mathrm{R}$ & $\mathrm{S}$ & $\mathrm{S}$ & $\mathrm{R}$ & $\mathrm{R}$ & $\mathrm{R}$ & $\mathrm{R}$ & I & $\mathrm{S}$ & $\mathrm{S}$ & $\mathrm{S}$ & $\mathrm{R}$ & $\mathrm{S}$ & $\mathrm{S}$ & $\mathrm{S}$ & I & I & I \\
\hline Amoxicillin & $\mathrm{R}$ & $\mathrm{R}$ & $\mathrm{R}$ & $\mathrm{R}$ & $\mathrm{R}$ & $\mathrm{R}$ & $\mathrm{R}$ & $\mathrm{R}$ & $\mathrm{R}$ & $\mathrm{R}$ & $\mathrm{R}$ & $\mathrm{R}$ & $\mathrm{R}$ & $\mathrm{R}$ & $\mathrm{R}$ & $\mathrm{R}$ & $\mathrm{R}$ & $\mathrm{R}$ & $\mathrm{R}$ \\
\hline Cefoperazone & $\mathrm{S}$ & $\mathrm{R}$ & $\mathrm{R}$ & $\mathrm{R}$ & $\mathrm{R}$ & $\mathrm{R}$ & $\mathrm{R}$ & $\mathrm{R}$ & $\mathrm{R}$ & $\mathrm{R}$ & $\mathrm{R}$ & $\mathrm{R}$ & $\mathrm{R}$ & $\mathrm{R}$ & $\mathrm{R}$ & $\mathrm{R}$ & $\mathrm{R}$ & $\mathrm{R}$ & $\mathrm{R}$ \\
\hline Erythromycin & $\mathrm{S}$ & $\mathrm{S}$ & $\mathrm{S}$ & $\mathrm{S}$ & I & $\mathrm{S}$ & $\mathrm{S}$ & $\mathrm{S}$ & $\mathrm{S}$ & $\mathrm{S}$ & $\mathrm{S}$ & $\mathrm{S}$ & $\mathrm{S}$ & $\mathrm{S}$ & $\mathrm{S}$ & $\mathrm{S}$ & $\mathrm{S}$ & $\mathrm{S}$ & $\mathrm{S}$ \\
\hline
\end{tabular}

The results showed a variation in the inhibitory effect depending on Bacillus strain and of the pathogenic bacterium (Table III). Five (5) strains have an inhibitory effect against all pathogens used. They belong to the species B. pumilus (NM 21 and NM 33), B. altitudinis (NM 16 and NM 24) and $B$. megaterium (NM 56). On the other hand, most strains (13) were able to inhibit the growth of $S$. aureus, Serratia odorifera and Salmonella $\mathrm{sp}$. The growth of $E$. coli was inhibited by eight strains (NM 21, NM 33, NM 5, NM 16, NM 24, NM 52, NM 56 and NM 73), but the areas of inhibition were generally smaller (diameter $\leq 12$ $\mathrm{mm})$ than those obtained with Three other pathogens. Fifteen (15) strains showed inhibitory activity against $S$. aureus with zones of inhibition of diameter between 9 and $16 \mathrm{~mm}$. The proportion of antisalmonellic strains was highest $(89.47 \%$ of the strains). Finally, the antibacterial activity of the strains was more pronounced with Serratia odorifera, strains11 produced zones of inhibition with a diameter $\geq 16 \mathrm{~mm}$.

Table III: Diameter of inhibition zones of growing

\begin{tabular}{|c|c|c|c|c|c|c|c|c|c|c|c|c|c|c|c|c|c|c|c|}
\hline & \multicolumn{19}{|c|}{ Bacterial strains } \\
\hline & \multirow{3}{*}{$\begin{array}{c}\mathrm{NM} \\
21\end{array}$} & \multirow{3}{*}{$\begin{array}{c}\mathrm{NM} \\
29\end{array}$} & \multirow{3}{*}{$\begin{array}{c}\mathrm{NM} \\
33\end{array}$} & \multirow{3}{*}{$\begin{array}{c}\mathrm{NM} \\
34\end{array}$} & \multirow{3}{*}{$\begin{array}{c}\mathrm{NM} \\
67\end{array}$} & \multirow{3}{*}{$\begin{array}{c}\mathrm{NM} \\
1\end{array}$} & \multirow{3}{*}{$\begin{array}{c}\mathrm{NM} \\
3\end{array}$} & \multirow{3}{*}{$\begin{array}{c}\mathrm{NM} \\
5\end{array}$} & \multirow{3}{*}{\begin{tabular}{|c|}
$\mathrm{NM}$ \\
16
\end{tabular}} & \multirow{3}{*}{$\begin{array}{c}\mathrm{NM} \\
24\end{array}$} & \multirow{3}{*}{$\begin{array}{c}\mathrm{NM} \\
52\end{array}$} & \multirow{3}{*}{$\begin{array}{c}\mathrm{NM} \\
56\end{array}$} & \multirow{3}{*}{$\begin{array}{c}\mathrm{NM} \\
65\end{array}$} & \multirow{3}{*}{\begin{tabular}{|c|}
$\mathrm{NM}$ \\
35
\end{tabular}} & \multirow{3}{*}{$\begin{array}{c}\mathrm{NM} \\
39\end{array}$} & \multirow{3}{*}{\begin{tabular}{c|}
$\mathrm{NM}$ \\
76
\end{tabular}} & \multirow{3}{*}{$\begin{array}{c}\mathrm{NM} \\
78\end{array}$} & \multirow{3}{*}{$\begin{array}{c}\mathrm{NM} \\
74\end{array}$} & \multirow{3}{*}{$\begin{array}{c}\mathrm{NM} \\
73\end{array}$} \\
\hline & & & & & & & & & & & & & & & & & & & \\
\hline Path & & & & & & & & & & & & & & & & & & & \\
\hline$E$. & 07 & 00 & 08 & 00 & 00 & 00 & 00 & 08 & 09 & 12 & 08 & 07 & 00 & 00 & 00 & 00 & 00 & 00 & 05 \\
\hline S. aureus & 11 & 13 & 15 & 10 & 12 & 00 & 13 & 00 & 11 & 14 & 16 & 12 & 13 & 00 & 00 & 15 & 11 & 16 & 09 \\
\hline Salmonella sp. & 14 & 17 & 15 & 12 & 14 & 12 & 13 & 08 & 13 & 13 & 11 & 14 & 16 & 12 & 00 & 15 & 13 & 14 & 00 \\
\hline Serratia odorifera & 07 & 05 & 18 & 18 & 18 & 00 & 00 & 00 & 09 & 16 & 00 & 21 & 22 & 25 & 18 & 28 & 18 & 18 & 00 \\
\hline
\end{tabular}

\section{Volume 6 Issue 1, January 2017 www.ijsr.net}




\section{International Journal of Science and Research (IJSR) \\ ISSN (Online): 2319-7064 \\ Index Copernicus Value (2015): 78.96 | Impact Factor (2015): 6.391}

\section{Discussion}

The different strains of Bacillus showed intrinsic enzymatic properties during ntoba mbodi fermentation. Indeed, the proteolytic activity manifested by all the strains indicates that most strains are able to ensure the degradation of the peptides and proteins of the cassava leaves resulting in the release of the amino acids and deamination to produce an alkalization fermentation food [20, 27].

This alkalization of the fermentation medium acts as a selective factor for alkaline-tolerant bacteria such as Bacillus spp [28]. The demonstration of the pectinolytic activity of strains suggests that spore-forming strains are also capable of degrading the skeletal structures of the cassava leaves cell wall and as consequence contributing to the softening of food. Previous works of [22] on Bacillus spp isolated from ntoba mbodi also reveal both pectinolytic and proteolytic activities (64\%), and only pectinolytic activity (36\%). Finally, the amylolytic strains would be able to hydrolyse the endogenous starch of cassava leaves into fermentable sugars. The small proportion of $\alpha$-amylase producing bacteria could be explained by catabolic repression, since in the presence of glucose the biosynthesis of amylases is generally suppressed in Bacillus spp. [23]. This work opens a way to constitute a biological ferment consisting of a consortium of spore-forming bacteria even with different activities.

In general, it was established that although there has been a loss of growth of all the bacteria in $\mathrm{pH} 2.0$ and 2.5, the number of viable cells is still important. The average survival rate of the most resistant strains (B. subtilis and $B$. amyloliquefaciens) at $\mathrm{pH} 2.0$ is $77.25 \%$. A survival rate above $92 \%$ at this $\mathrm{pH}$ value for 3 hours was reported by [38] basing on strains B. licheniformis, B. subtilis and B. amyloliquefaciens isolated from a traditional fermented food of Mongolia. According to the study described by [30], the ideal $\mathrm{pH}$ value for the isolation of strains very resisting to acid $\mathrm{pH}$ is 2.5. In this study, $63.15 \%$ of strains, $B$. megaterium (NM 56 and NM 65), B. amyloliquefaciens (NM 76 and NM 78), B. safensis (NM 3 and NM 5), B. altitudinis (NM 24 and NM 52), B. pumilus (NM 21 and NM 29) and B. subtilis (NM 35 and NM 39) showed a survival rate greater than $70 \%$ after 4 hours of acid stress. This result indicates that these bacteria would be able to resist in vivo conditions of gastric acidity. Survival values greater than $83 \%$ were recorded for $B$. subtilis and $B$. amyloliquefaciens strains. This result differs from study described [17] stating that only Bacillus laevolacticus (DSM6475) could survive at $\mathrm{pH} 2.5$ for 3 hours with the rate of $86 \%$.

The biliary concentrations used to assess the ability of bacteria to survive biliary stress vary from $0.01 \%$ to 7.5 $\%$ [34]. According to [12, 13], $0.3 \%$ would be the appropriate concentration for selecting probiotics. In our study most strains showed an excellent growth at this concentration. This could be supposing that they would also be able to tolerate biliary stress in vivo. At the molecular level chloramphenicol and erythromycin act on the target bacteria by inhibiting protein synthesis, whereas the inhibition of peptidoglycan synthesis constitutes the mode of action of amoxicillin and cephalosporin [40]. The observation of bacterial resistance to antibiotics can be explained by various mechanisms: production of bacterial enzymes capable of inactivating them, impermeability of bacterial cells or changes in structure [18].

Very little information are available on antimicrobial susceptibility patterns of Bacillus spp. let alone the patterns of antimicrobial susceptibility of Bacillus spp isolated from African fermented foods [2]. The (intermediate) response of $B$. licheniformis to chloramphenicol correlates with the results of [8], who found low sensitivity to chloramphenicol in $B$. licheniformis isolated from the bikalga representing the fermented seeds of Hibiscus sabdariffa. This result also corroborates the report by [32], which reports the chloramphenicol resistance of probiotic $B$. licheniformis strain 31 from Eastern Europe. The sensitive responses of $B$. subtilis and $B$. amyloliquefaciens to chloramphenicol and erythromycin are also consistent with the results of [2], which suggest the absence of resistance genes for these two antibiotics in strains of B. subtilis and B. amyloliquefaciens isolated from bikalga. On the other hand, resistance of Bacillus subtilis to chloramphenicol has been reported by [31]. Similarly, resistance of Bacillus licheniformis to erythromycin has been well understood [3]. Almost all strains are resistant to amoxicillin and cefoperazone. All strains belonging to the same species are resistant to the aforementioned two antibiotics. This interesting result supposes that it could be intrinsic resistance. Contrary to the acquired resistance, the latter represents only a negligible risk of propagation [35].

The observation of an inhibitory effect on the growth of pathogenic bacteria indicates that these strains are likely to play an essential role in the biopreservation of ntoba mbodi. This inhibitory action could be due to the production of antibacterial substances. Indeed, during the logarithmic and / or stationary growth phase, Bacillus spp. are able to produce antimicrobial compounds, such as subtilisin, bacitracin, amicoumacin, gramicidin, coagulin, subtilin, Iturin, polymyxin, colistin and surfactin $[1,25]$. These bacteriocins act by forming pores in the cytoplasmic membrane of the target cells, resulting in release of the intracellular content and death of the bacterium [39]. All the strains have the same spectrum of action with respect to the pathogens tested. However, some intra spectral variations have been observed: B. pumilus (NM 21) and B. pumilus (NM 33) inhibit the growth of $E$. coli strains, whereas the strains NM 29, NM 34 and NM 67 of the same species do not exert any antagonism towards this pathogen. The antagonistic effect against $S$. aureus of $B$. licheniformis, $B$. subtilis and $B$. amyloliquefaciens strains was reported [38]. However, contrary to our results, the strains belonging to the same species have an inhibitory effect on the growth of $E$. coli. The inhibition of growth of $S$. aureus, $E$. coli and Salmonella typhimurium by B. pumilus strain isolated from soumbala (fermented seeds of Parkia biglobosa) has also been reported [29]. In contrast, B. subtilis strains isolated from the same food inhibit the growth of these three pathogens. Similarly, [15] have shown that B. subtilis strains isolated from alkaline-fermented feeds produce metabolites that inhibit the growth of $S$. aureus, E. coli, and $S$. typhimurium. These different pieces of information prove

\section{Volume 6 Issue 1, January 2017




\section{International Journal of Science and Research (IJSR) \\ ISSN (Online): 2319-7064 \\ Index Copernicus Value (2015): 78.96 | Impact Factor (2015): 6.391}

that the antibacterial activity is specific to each strain and cannot be extrapolated from one strain to another, even within the same species.

\section{Conclusion}

The spore-forming strains studied have in vitro interesting fermentation and probiotic profiles such as the $\alpha$-amylases, proteases and pectinases production, antibacterial activity and resistance to stress in the gastrointestinal transit. The best profiles are showing by NM 39, NM 76, NM 78, NM 1, NM 5, NM 16, NM 33 and NM 56 corresponding to Bacillus subtilis, B. amyloliquefaciens, B. safensis, B. altitudinis, B. pumilus and $B$. megaterium. Basing on results, the eight strains of genus Bacillus strains studied possess good fermentation potential could be used as a leaven and can also be considered separately as potential probiotic candidates. The results of our study are an essential first step in the development of a probiotic ferment to control production and to valorize ntoba mbodi as probiotic food.

In order to better elucidate the beneficial effect observed in these strains, other studies deserve to be developed, such as, evaluation of their capacity for adhesion to the epithelial cells of the intestine, evaluation of linamarasic activity and evaluation of the impact of physicochemical factors on the production of enzymes and other interesting metabolites.

\section{Acknowledgements}

We thank Dr. Labia Irene I. Ouoba, Researcher at Microbiology Research Unit of Faculty of Life Sciences and Computing, London Metropolitan University, United Kingdom, for her help, financial and material support.

\section{References}

[1] Abriouel H., Franz C.M.A.P., Omar N.B., and Galvez, A. 2011.Diversity and applications of Bacillus bacteriocins. FEMS Microbiol.Rev.35: 201-232.

[2] Adimpong D.B., Sorensen K.I., Thorsen L., StuerLauridsen B., Abdelgadir W.S., Nielsen D.S., Derkx P.M.F and Jespersena, L. 2012 Antimicrobial susceptibility of Bacillus strains isolated from primary starters of African traditional bread production and characterization of the bacitracin operon and bacitracin biosynthesis. Applied and Environnemental Microbiology p. 7903-7914.

[3] Barbosa M.T., Serra R.C., La Ragione M.R., Woodward J.M, and Henriques A.O. 2005. Screening for Bacillus isolates in the Broiler Gastrointestinal Tract. Appl.Environ. Microbiol, 71: 968-978.

[4] Benabdallah N. 2010. Isolement et caractérisation de bactéries à fort potentielprobiotique à partir du tractus gastro-intestinal de volaille. Mémoire pour l'obtention du grade de maître es sciences (M.Sc). Université Laval Québec.

[5] Bertheau Y., Maggidi-Hervan E., Kotoujansky A., Nguyen-The C., Andro T, and Coleno A. 1984. Detection of depolymerase isoenzymes after electrophoresis electrofocusing or in titration curve. Anal. Biochem, 139: 383-389.
[6] Bouzaine T, ELMajdoub T., Thonart PH., et Damdi M. (2004): Sélection des bactéries lactiques probiotiques d'origine animale. Microbio.Hyg.Alim. 16: 28.

[7] Clinical and Laboratory Standards Institute (CLSI). 2010. Approved standard M2- A10.

[8] Compaoré C. S., Jensens L. B., Diawara B., Ouédraogo G.A., Jakobsens M, and Ouoba L.I.I. 2013. Resistance to antimicrobials and acid and bile tolerance of Bacillusspp isolated from Bikalga, fermented seeds of Hibiscus sabdariffa. AcademicJournals, 11: 408-414.

[9] Doleyres Y., Paquin C., LeRoy M, and Lacroix C. 2002. Bifidobacterium longumATCC 15707 cell production during free- and immobilized-cell cultures in MRSwheypermeate medium, Appl. Microbiol.Biotechnol, 60:168-173.

[10]Fleming H.P., Etchells J.L, and Costilow R.N. 1975.Microbial inhibition by an isolate of Pediococcusfrom cucumber brines. Appl. Microbiol. 30: 1040-1042.

[11] Gaggia F., Mattarelli P and Biavati B. 2010.Probiotics and prebiotics in animal feeding for safe food production. Trends in Food Science \& Technolog.22, $.58-\mathrm{S} 66$

[12] Gilland SE., Staley TE and Busht J. (1984): Importance of bile tolerance in lactobacilli used as diatary adjunct. $\mathrm{J}$ Dairy Sc. 67: 365-378.

[13] Goldin B and Gorbach, S. 1992. Probiotics for humans. In R. Fuller (Ed.), Probiotics: the scientific basis (pp. 355-376). London: Chapman and Hall.

[14] Guiraud J.P. 2003. Microbiologie Alimentaire. Tec \&Doc, Dunod.Paris. 90 -292.

[15]Guo X., Li D., Lu W., Piao X and Chen X. 2006.Screening of Bacillus strains as potential probiotics and subsequent confirmation of the in vivo effectiveness of Bacillus subtilisMA139 in pigs. Antonie van Leeuwenhoek, 90:139-146.

[16] Hassan M., Kjos M., Nes I.F., Diep D.B and Lotfipour, F. 2012. Natural antimicrobial peptides from bacteria: characteristics and potential applications to fight against antibiotic resistance. J. Appl. Microbiol. 113(4): 723736.

[17] Hydrominus B., Le Marrec P., Hadj Sassi A, and Deschamps A. 2000. Acid and bile tolerance of spores forming lactic acid bacteria. Int. J. Food Microbiol, 61: 193- 197.

[18] Jacoby G. A and Larcher ARCHERGL. New mechanisms of bacterial resistance to antimicrobial agents. NEngl J Med 1991; 324: 601-12.

[19] Kéléké S. 1996. Le rouissage de manioc: contribution à l'étude du phénomène de ramollissement des racines de manioc. Thèse, 148 pages. Université de Paris XII Val de Marne.

[20]Kiers J.L, Van Laeken A.E.A., Rombouts F.M, and Nout M.J.R. 2000.In vitro digestibility of Bacillus fermented soya bean. Int. J. Food Microbiol, 60:163169.

[21] Kobawila S.C., Louembé D., Kéléké S, and Traoré A.S. 2003. Aspects physicochimiques et biochimiques de la fermentation des feuilles en Ntobambodi. ProcédéBiologique et Alimentaire, 1(1): 106-109.

[22] Louembé D., Kobawila S.C., Bouanga G. and Kéléké S. 2003. Etude microbiologique des feuilles fermentées de manioc: Ntobambodi. Tropicultura, 21(3) 106-111. 


\section{International Journal of Science and Research (IJSR) \\ ISSN (Online): 2319-7064 \\ Index Copernicus Value (2015): 78.96 | Impact Factor (2015): 6.391}

[23] Maktouf, S., Moulis, C., Kamoun, A., Chaari, F., EllouzChaabouni, S, and Remaud-Simeon, M. 2013. A laundry detergent compatible lichenase: Statistical optimization for production under solid state fermentation on crude millet Industrial Crops and Products, 43: 349-354.

[24] Midassirou B., Mahdhi A., Chaieb K., Bakhrouf A. 2012. Recherche des bactéries lactiques et étude in vitro de leurs propriétés probiotiques. Rev. Microbiol. Ind. San etEnvironn. Vol 6, $N^{\circ} 2, p:$ 147-163.

[25] Moran S., Roberto, K., Paradisi F., Rai D.K, and Murphy C.D. 2010.Production of lipopeptides in Bacillus sp. CS 93 isolated from Pozol. FEMS Microbiology Letters. 304: 69-73

[26] Nicholson W.J., Munakata N., Horneck G., Melosh H.J., and Setlow P. 2000.Resistance of Bacillus endospores to extreme terrestrial and extraterrestrial environments. Microbiol. Mol. Biol. Rev. 64: 548-572.

[27] Ouoba L.I.I., Rechinger K.B., Barkholt V., Diawara B., Traoré A.S, and Jakobsen M. 2003a. Degradation of proteins during the fermentation of African locust bean (Parkia biglobosa), by strains of Bacillus subtilis and Bacillus pumilus for production of Soumbala.Journal of applied microbiology, 94: 396-402.

[28] Ouoba L.I.I., Diawara B., Jespersen I, and Jakobsen M. 2007.Antmicrobial activity of Bacillus subtilisand Bacillus pumilus during the fermentation of African locust bean Parkia biglobosa, for soumbala production. J Appl Microbiol, 102: 963- 970.

[29] Ouoba L.I.I., Parkouda C., Diawara B., Scotti C. and Varnam A.H. 2008a. Identification of Bacillus spp from Bikalga, fermented seeds of Hibiscus sabdariffa: phenotypic and genotypic characterization. $J$ Appl Microbiol, 104:122-131.

[30] Pennachia C., Ercolini D., Blaiotta G., Pepe O., Mauriello G, and Villani F. 2004. Selection of Lactobacillus strains from fermented sausages for their potential used as probiotics. Meat Sci, 67:309-317.

[31] Senesi S., Celandroni F., Tavanti A, and Ghelardi E. 2001. Molecular characterization and identification of Bacillus clausiistrains marketed for use in oral bacteriotherapy. Appl. Environ. Microbiol, 67:834-839.

[32] Sorokulova I.B., Pinchuk I.V, Denayrolles M., Osipova I.G., Huang JM., Cutting S.M, and Urdaci M.C.
2008.The safety of two Bacillus probiotic strains forhuman use. Digestive Diseases Sci, 53: 954-963.

[33] Tadesse G., Ephraim E, and Ashenafi M. 2004. Assessment of the antimicrobial activity of lactic acid bacteria isolated from Borde and Shamita, traditional Ethiopian fermented beverages, on some foodborne pathogens and effect of growth medium on the inhibitory activity. Int. J. Food Safety, 5:13-20.

[34] Turpin W., Humblot C., Thomas M, and Guyot J.P. 2011. Lactobacilli as multifaceted probiotics with poorly disclosed molecular mechanisms. Int $J$ Food Microbiol, 143: 87-102.

[35] Van ReenenC. A, and Dicks L.M. 2011.Horizontal gene transfer amongst probiotic lactic acid bacteria and other intestinal microbiota: what are the possibilities? A review. Arch. Microbiol, 193: 157-168.

[36] Vouidibio M.A.B. 2016. Identification génotypique et étude du potentiel fermentaire et probiotique des Bacillus du Ntoba mbodi.Thèse, Doctorat unique, Faculté des Sciences et Techniques. Université Marien Ngouabi. République du Congo.

[37] Vuillemard J.C., Amiot J, and Gauthier S. 1986. Evaluation de l'activité protéolytique de bactéries lactiques par une méthode de diffusion sur plaque. Microbiol. Alim. Nutr, 3: 27-332.

[38] Wang Y., Zhang L., Zhang H., Liu, W., Zhang Y., Zhang $X$, and Sun T. 2010. In vitro assessment of probiotic properties of Bacillus isolated from naturally fermented congee from Inner Mongolia of China. World J MicrobiolBiotechnol, 26(8):1369-1377.

[39] Wang G., Manns D.C., Churey J.J., and Worobo R.W. 2014a. Development of a homologous expression system development and the systematic site directed mutagenesis analysis of thurincin $\mathrm{H}$, a bacteriocin produced by Bacillus thuringiensisSF 361. Appl. Environ. Microbiol. 80 (12); 3576-3584.

[40]Zomahoun C.I, N. 2004. Evaluation de la sensibilité aux antibiotiques des bactéries isolées des infections urinaires au laboratoire de bactériologie du centre national hospitalier universitaire H.K.M de Cotonou. Thèse, Doctorat d'Etat, Faculté de médecine de pharmacie et d'odonto-stomatologie. Université du Mali. 
International Journal of Science and Research (IJSR)

ISSN (Online): 2319-7064

Index Copernicus Value (2015): 78.96 | Impact Factor (2015): 6.391

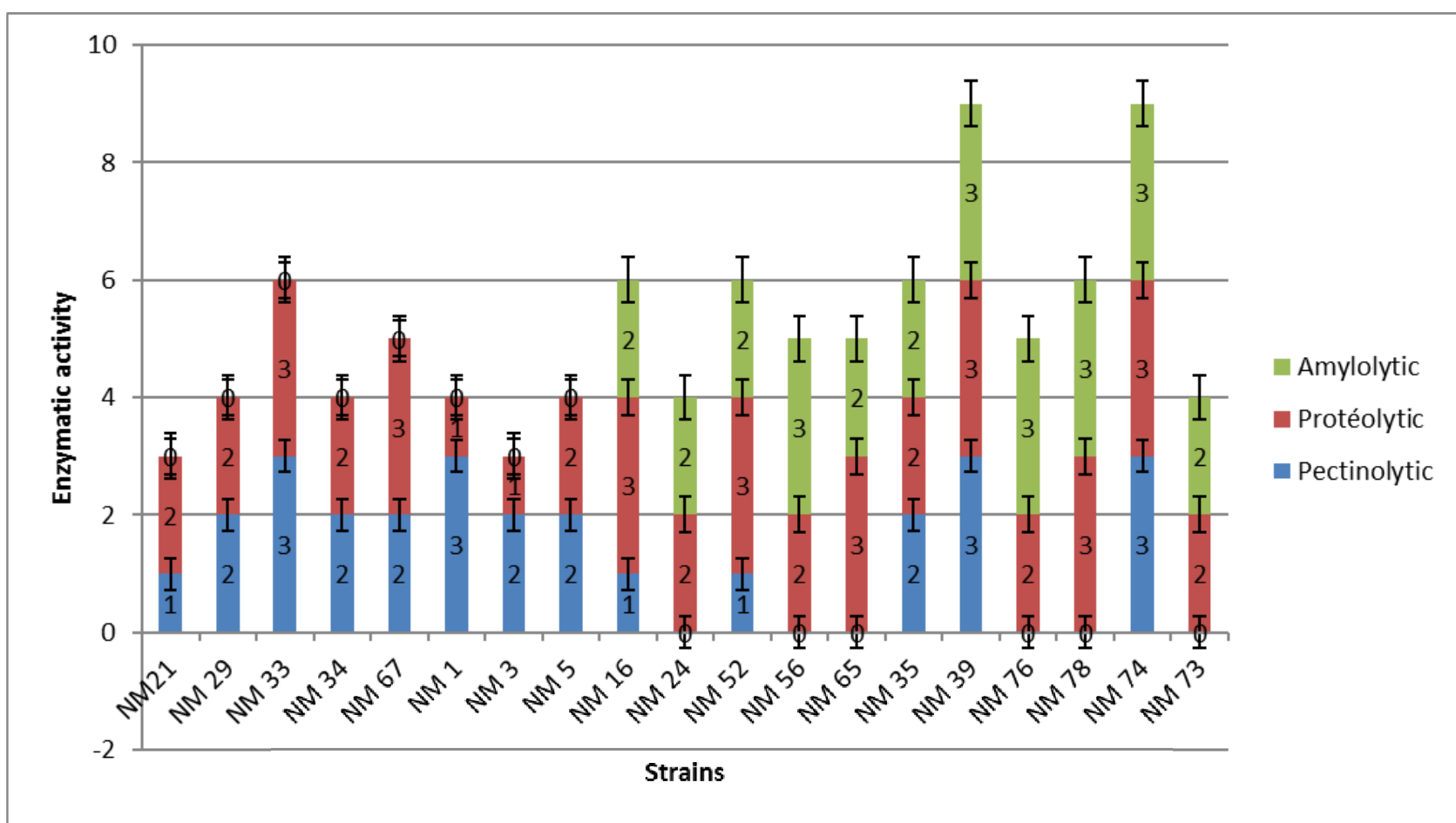

Figure 1: Enzymatic activities of bacteria

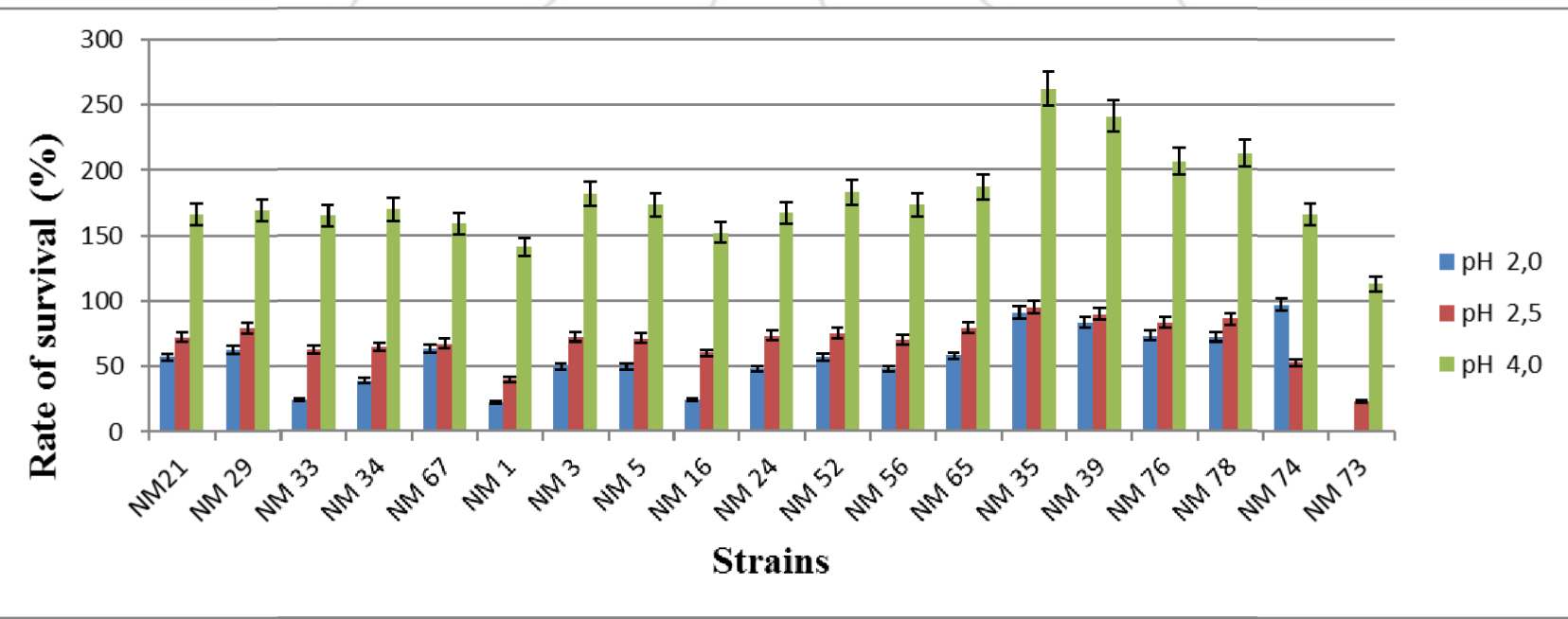

Figure 2: Survival rate of strains depending on acidic $\mathrm{pH}$

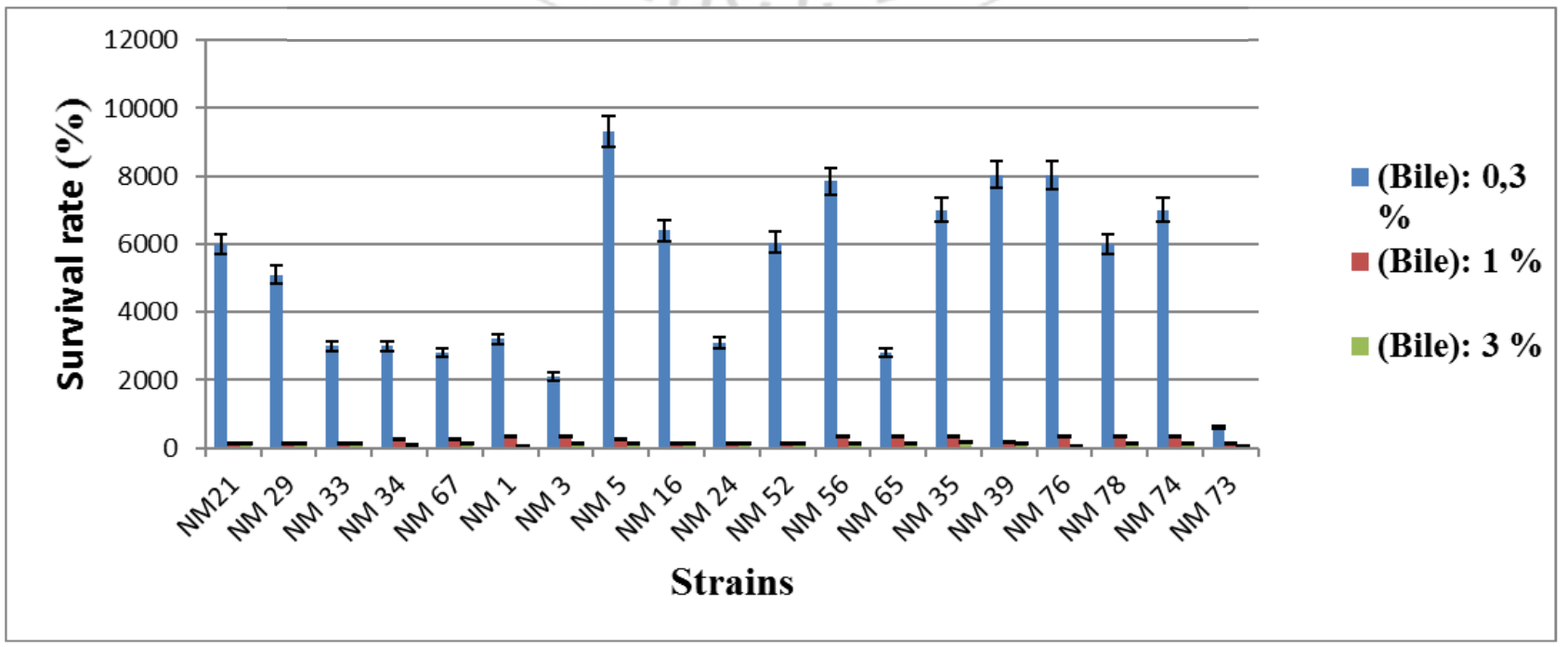

Figure 3: Survival rate of strains depending biliary concentration

Volume 6 Issue 1, January 2017

www.ijsr.net

Licensed Under Creative Commons Attribution CC BY 